\title{
Klinisch redeneren in het fysiotherapie onderwijs
}

\author{
D. Gerards-Last, J. Geraets
}

\section{Samenvatting}

Inleiding: Het noodzakelijke denkproces voor het nemen van de juiste beslissingen tijdens het praktische, fysiotherapeutische handelen wordt klinisch redeneren genoemd. In het algemeen wordt aangenomen dat flexibiliteit in het denkproces en een goed gestructureerde kennisbasis hieraan ten grondslag liggen.

Vraagstelling: Dit onderzoek is gericht op de vraag of in de perceptie van de studenten het competentiegericht onderwijs (CGO), ingericht volgens het 4 C/ID-model, het klinisch redeneren binnen de domeinen flexibiliteit in het denkproces en kennisstructuur, meer bevordert dan het meer traditionele, probleemgestuurde onderwijs (PGO).

Methode: Aan de hand van een vragenlijst die het klinisch redeneren in kaart brengt (met subschalen in de domeinen flexibiliteit in het denkproces en kennisstructuur), zijn vierdejaars studenten van het cohort 2004 (n=58) en van het cohort 2006 (n=34) van de opleiding Fysiotherapie van de Hogeschool Zuyd te Heerlen met elkaar vergeleken. Daarbij werd een ongepaarde student t-toets uitgevoerd.

Resultaten: Het resultaat van dit onderzoek laat zien dat in de perceptie van de studenten een statistisch significante verbetering is opgetreden in het klinisch redeneren van de vierdejaars studenten uit het cohort 2006 die het CGO volgden in vergelijking met studenten uit het cohort 2004 die het meer traditionele PGO doorliepen (klinisch redeneren $p=0.01$ en meer specifiek in het domein flexibiliteit in denken $p=0.01$ en kennisstructuur $p=0.03$ ).

Conclusie en discussie: Meer onderzoek is nodig naar de wijze waarop CGO het klinisch redeneren van studenten helpt verbeteren, naar de factoren die dit proces mede beïnvloeden en naar objectieve meetinstrumenten om het klinisch redeneren te kunnen evalueren. (Gerards-Last D, Geraets J. Klinisch redeneren in het fysiotherapie onderwijs. Tijdschrift voor Medisch Onderwijs 2011;30(5):226-236.)

\section{Inleiding}

In het medisch onderwijs is het klinisch redeneren een belangrijk punt van aandacht. Over de vraag hoe experts tot de juiste diagnose komen wordt in de literatuur al meer dan dertig jaar veel geschreven. ${ }^{1}$ Onderzoek naar klinisch redeneren is vooral uitgevoerd in het domein van de geneeskunde..$^{2-5}$.Daaruit blijkt dat er in het diagnostisch en therapeutisch proces een relatie bestaat tussen het vermogen tot klinisch redeneren en het nemen van de juiste beslissingen. ${ }^{6}$
Binnen het domein van de fysiotherapie is nog weinig onderzoek verricht naar klinisch redeneren. Omdat men er vanuit mag gaan dat er grote gelijkenis in het proces van klinisch redeneren bestaat binnen (para)medische disciplines, is het aannemelijk dat goed klinisch redeneren ook in de fysiotherapiepraktijk van groot belang is voor efficiënte en effectieve diagnostiek en behandeling.

In het beroepsprofiel voor de fysiotherapeut wordt klinisch redeneren als volgt gedefinieerd: 
"klinisch redeneren omvat de mentale processen van verzamelen, interpreteren en structureren van de informatie waardoor de fysiotherapeut in staat is op grond van zijn biomedische, gedragswetenschappelijke en fysiotherapeutische kennis een probleem te verhelderen en op te lossen'.

In het algemeen wordt aangenomen dat aan het nemen van de juiste beslissing cognitieve vaardigheden, waaronder een goed gestructureerde kennisbasis, ten grondslag liggen ${ }^{8-10}$ Graber $^{11}$ ordent de oorzaken van medische fouten in drie categorieën, waarbij onderscheid wordt gemaakt tussen factoren die te maken hebben met a) de patiënt (bijvoorbeeld: simuleert hij of niet), b) het systeem waarin gewerkt wordt (bijvoorbeeld: is het instrumentarium deugdelijk) en c) de cognitieve vaardigheden van de beroepsbeoefenaar. Over deze cognitieve vaardigheden geven Bordage et al. ${ }^{8}$ aan dat de student naast een goede kennisstructuur ook moet beschikken over voldoende flexibiliteit in het denkproces. Met andere woorden: de student zal zijn professionele vakkennis wendbaar moeten kunnen toepassen.

In het schooljaar 2005/2006 is in de opleiding Fysiotherapie, Hogeschool Zuyd te Heerlen, het competentiegericht onderwijs (CGO) ingevoerd. ${ }^{12}$ Het beschikbaar komen van het landelijk ontwikkelde competentieprofiel is voor de constructie van dit CGO van belang geweest. ${ }^{10}$ Daarnaast was uit uitgevoerde evaluaties in het werkveld duidelijk geworden dat studenten te weinig in staat waren de transfer van het binnenschools geleerde naar de echte praktijk te maken. Dit is een van de redenen dat in 2005 is besloten het curriculum te herzien en hierbij het ' 4 Componenten/Instruction Design' (4 C/ID model $)^{13}$ als leidraad te hanteren. Het model is uitgebreid beschreven in wetenschappelijke artikelen en diverse boeken. ${ }^{14-17}$
Het curriculum van de opleiding Fysiotherapie te Heerlen wordt al sinds 1998 gekarakteriseerd als Probleem Gestuurd Onderwijs (PGO), waaraan een + gekoppeld is (PGO+ vorm). De + staat voor volledige integratie van theorie met vaardigheden. Ook na de herziening in 2005 werd dit $\mathrm{PGO}+$ onderwijs gehandhaafd. Er is geen apart skillslab; de vaardigheden die getraind worden vloeien rechtstreeks voort uit de op dat moment aan de orde zijnde authentieke leertaak.

Deze studie probeert een antwoord te vinden op de volgende vraag: is er in de perceptie van de studenten van de opleiding Fysiotherapie, Hogeschool Zuyd te Heerlen, een verbetering opgetreden wat betreft de flexibiliteit in het denkproces en de kennisstructuur als voorwaarden voor het klinisch redeneren door toepassing van het CGO met behulp van het 4 C/ID-model (nieuwe curriculum)?

\section{Het 4 C/ID model}

Het 4 C/ID model sluit goed aan op de trends in het Nederlandse onderwijs, zoals meer aandacht voor a) de ontwikkeling van professionele competenties, b) de transfer van het geleerde naar nieuwe situaties en nieuwe problemen, en c) de ontwikkeling van generieke competenties die belangrijk zijn om een leven lang te blijven leren. ${ }^{14}$

De vier componenten waarop het 4 C/ID model is gebaseerd staan voor a) de leertaak (authentieke casus), b) de deeltaak (routines), c) de ondersteunende informatie en d) de 'just in time' (JIT) theorie. ${ }^{13}$ Door het implementeren van deze componenten in het curriculum wordt de relatie tussen mentale modellen, cognitieve strategieën en praktische vaardigheden versterkt. In de beroepspraktijk verstaat de expert immers juist de kunst deze drie aspecten te integreren en te combineren. ${ }^{14}$ De belangrijkste elementen uit het $4 \mathrm{C} / \mathrm{ID}$ model, die in het bijzonder het klinisch redeneren helpen 
bevorderen, zijn het gebruik van authentieke leertaken en daarmee de 'whole-task' benadering. De praktijk bepaalt in zekere mate de context waarin geleerd moet worden.

Tegenwoordig erkent men dat de meeste klinische problemen context-afhankelijk zijn en dat de transfer van het ene naar het andere probleem beperkt mogelijk is. ${ }^{18} \mathrm{Om}$ effectief te kunnen redeneren moet de (toekomstige) beroepsbeoefenaar beschikken over degelijke beroepsspecifieke kennis van waaruit context-afhankelijke kennis kan worden afgeleid. ${ }^{19}$ Bovendien is het uitgangspunt van het model dat meerdere variaties binnen dezelfde moeilijkheidsgraad (taakklasse) worden aangeboden. Dit stelt de student in staat een rijke, geïntegreerde kennisbasis te ontwikkelen die de kans vergroot dat er in nieuwe situaties bruikbare kennis in het geheugen gevonden kan worden. ${ }^{14}$

Het aanbod van variaties in leertaken zal de flexibiliteit in het denkproces bevorderen en de transfer van het eerder geleerde naar de nieuwe situatie vergemakkelijken. Klinisch redeneren vraagt veel oefening met vaak onvolledige informatie in een authentieke casus. ${ }^{20}$ Dit denkproces draagt niet een generaliserend maar een individualiserend karakter. ${ }^{21}$ Dat wil zeggen dat er geen kant en klare gestandaardiseerde en geprotocolleerde oplossingen beschikbaar zijn; ieder (dreigend) gezondheidsprobleem in de gegeven context vraagt om een weloverwogen klinische redenering om tot het juiste handelen te kunnen komen. Het analyseren, afwegen en heroverwegen van gegevens zal een zorgvuldige keuze van handelen ontlokken. Door herhaling in varianten wordt deze cognitieve vaardigheid telkens opnieuw geoefend.

De toenemende moeilijkheidsgraad, van niveau 1 (novice) via niveau 2 (gevorderde) naar niveau 3 (de beginnende beroepsbeoefenaar $)^{10}$ in de verschillende leerjaren, draagt ertoe bij dat de student de nieuw aangeboden kennis en vaardigheden gemakkelijker aan zijn bestaande kennisconstructen kan koppelen. Tenslotte zal het oefenen van deeltaken, waarin routines eerst onder volledige begeleiding, vervolgens via vermindering van ondersteuning naar een volledig zelfstandige beheersing worden gedrild, ertoe bijdragen dat er minder aandacht nodig is voor de handeling zelf en er meer ruimte is voor cognitieve processen gericht op het klinisch redeneren.

Het curriculum is bedoeld om van de aankomende student een beginnend beroepsbeoefenaar te maken. Het is ontwikkeld om het werk- en denkniveau van de student te bevorderen. Dat blijft een uitermate complex gegeven. Velerlei omstandigheden, zoals ervaring, cultuur, leeftijd etc., bepalen hoe iemand zich ontwikkelt. Het is een complex samenspel van vele interne en externe factoren en wordt daarom ook wel een 'black box' genoemd. ${ }^{22}$

Het is voor docenten een grote uitdaging om in dit complexe speelveld te onderzoeken hoe het klinisch redeneren aangeleerd kan worden en vooral ook of het door veranderingen in het curriculum is bevorderd.

\section{Methode}

Er is gekozen voor een onderzoeksdesign waarin na de voltooiing van hun stage een aselecte steekproef vierdejaars studenten (cohort 2004) uit het meer traditionele PGO-curriculum werd vergeleken met een aselecte steekproef vierdejaars studenten uit het nieuwe CGO-curiculum (cohort 2006).

Het klinisch redeneren werd gemeten aan de hand van de vragenlijst "Diagnostic thinking inventory" (DTI) van Bordage et al. ${ }^{8}$ (zie Box 1). Hiertoe werd de vragenlijst opnieuw vanuit het Engels naar het Nederlands vertaald volgens de 'backward trans- 
Box 1. Vertaalde vragenlijst "Diagnostic thinking inventory (DTI) van Bordage et al. ${ }^{8}$

1. Wanneer de patiènt zijn/haar symptomen presenteert,

Denk ik na over de symptomen in precies dezelfde

bewoordingen als de patiënt gebruikte

\section{Bij het in overweging nemen van elke diagnose}

Probeer ik hun relatieve belang te evalueren

3. Met betrekking tot het nadenken over diagnostische mogelijkheden,

Ik denk al vroeg in de casus na over diagnostische

mogelijkheden

4. Tijdens het vraaggesprek met de patiènt,

Lijkt het vaak alsof er zich een idee in mijn hoofd vastzet over wat mis is met de patiënt

5. Tijdens het vraaggesprek

Neig ik ertoe mijn eigen draad kwijt te raken als ik

de gedachtelijn van de patiënt volg

6. Wanneer het aankomt op het nemen van een beslissing over een diagnose,

Vind ik het niet erg om mijn diagnostische

beslissingen over een casus uit te stellen

()

$\square \square \square$

7. Als de patiènt zijn of haar symptomen en verschijnselen duidelijk heeft gepresenteerd,

Denk ik daarover na in de bewoordingen van de patiënt

\section{Met betrekking tot de routine anamnese}

Heb ik vaak het gevoel dat ik de routine anamnese niet afdoende afgehandeld heb

9. Als de patiènt zijn/haar verhaal vertelt en de casus zich openbaart,

Vind ik het vaak moeilijk om te onthouden wat er gezegd is

10. Tijdens het verloop van een vraaggesprek merk ik dat

Sommige belangrijke stukken informatie mij bijzonder lijken op te vallen

11. Wanneer ik geen duidelijkheid krijg uit de symptomen van de patiènt,

Ga ik verder met het verzamelen van nieuwe informatie om nieuwe ideeën te krijgen

12. Bij het overwegen van de diagnostische mogelijkheden,

Kom ik vaak met onwaarschijnlijke diagnoses

13. Tijdens het verzamelen van informatie over een patiènt

Lijken de verschillende delen informatie in mijn hoofd vaak vanzelf naar elkaar toe te groeien
Denk ik na over de symptomen in meer abstracte termen dan de uitdrukkingen die door de patiënt gebruikt werden (b.v. "een duur van 4 dagen" wordt "acuut"; "twee handen" wordt "bilateraal")

Probeer ik hen hetzelfde belang of gewicht te geven

Ik verzamel eerst de klinische informatie en ga er daarna over nadenken

Vind ik het meestal eenvoudig om de verschillende mogelijke diagnoses te verkennen

Kan ik mijn eigen gedachten helder houden, zelfs als ik de gedachtelijn van de patiënt volg

Voel ik me verplicht om voor een bepaalde diagnose te gaan zelfs als ik me er niet helemaal zeker over voel

Vertaal ik ze in gedachten in medische termen (b.v. een verdoofd gevoel wordt paresthesie of paralyse)

Handel ik de routine anamnese meestal naar mijn tevredenheid af

Kan ik meestal goed onthouden wat er gezegd is

Ik het vaak moeilijk vind te weten welke stukken informatie ik moet onthouden

Vraag ik de patiënt die symptomen duidelijker te beschrijven

Zoek ik het meestal in de goede hoek

Heb ik vaak moeite te zien hoe de stukjes informatie bij elkaar horen

14. Wanneer de diagnose bekend wordt en ik me realiseer dat ik het aanvankelijk niet gezien had,

Komt dat vaak omdat ik de ziekte wel kende, maar

vergat daar aan te denken

Komt dat vaak omdat ik niet genoeg weet over de ziekte

15. Tijdens het klinische vraaggesprek,

Kan ik mezelf er niet toe brengen sommige informatie als irrelevant af te doen

Heb ik er geen problemen mee sommige informatie als irrelevant af te doen 
Box 1. Vervolg

16. Wanneer ik geen duidelijkheid krijg uit de symptomen en verschijnselen van de patiënt,

Ga ik verder met het verzamelen van nieuwe informatie voor een nieuw perspectief

17. Wanneer ik een aantal mogelijke diagnoses in overweging neem,
Neigen de diagnoses ertoe aan elkaar gerelateerd te zijn
Merk ik meestal dat ik anticipeer op mogelijke abnormale verschijnselen en symptomen die bij die diagnose passen
Bekijk ik ze eerst vanuit een ander perspectief voordat ik verder ga

Neigen de diagnoses ertoe divers te zijn

19. Wanneer ik zeer weinig weet over een bepaald type ziekte,

Kan ik toch meestal met een diagnose komen $\quad \square \quad \square \quad \square \quad \square \quad \square \quad \square \quad \square \quad$ Heb ik grote moeilijkheden om tot een diagnose te komen 20. Bij het overwegen van de verschijnselen en symptomen van de patiënt,

Denk ik aan hen in absolute termen zoals de patiënt ze vermeldde.

Denk ik aan hen in termen van mogelijke tegenstellingen (b.v. progressief vs acuut; unilateraal vs bilateraal; spastisch vs slap)

21. Wanneer ik veel weet over een bepaald type ziekte en een diagnose moet stellen,

Vind ik het relatief eenvoudig om een diagnose toe

te kennen

Lijkt het er vaak op of ik alle kanten uit kan en vind ik het moeilijk om een diagnose toe te kennen

22. Naarmate de anamnese vordert en ik al wat ideeën heb over de mogelijke diagnose(s),

Geeft nieuwe informatie me vaak meer ideeën

Geeft nieuwe informatie me niet vaak meer ideeën

23. Wanneer ik een anamnese afneem, merk ik dat

Ik al nieuwe ideeën kan krijgen als ik de bestaande

informatie in gedachten overzie

Ik nieuwe informatie nodig heb om te zorgen dat ik een nieuw idee over de casus krijg

24. Wanneer de patiènt onnauwkeurige of dubbelzinnige uitdrukkingen gebruikt,

Laat ik hem of haar doorgaan om de voortgang van

het vraaggesprek te behouden

Laat ik hem of haar precies duidelijk maken wat hij/zij bedoelde voordat ik verder ga

25. Na een vraaggesprek met een patiënt,

Denk ik zelden dat ik nog andere dingen had moeten vragen in verband met de ziekte van de patiënt

Denk ik vaak dat ik nog andere dingen had moeten vragen in verband met de ziekte van de patiënt

26. Wanneer er zich informatie voordoet die me doet denken aan een mogelijke diagnose,

Zorgt het er vaak voor dat ik terug ga naar eerdere informatie om te zien of het bij elkaar past of niet

27. Over de diagnose die ik uiteindelijk stel,

Heb ik meestal weinig twijfels

28. Bij het nemen van een diagnostische beslissing,

Neem ik de beslissing door elke mogelijke diagnose op zichzelf te overwegen
Zorgt het er zelden voor dat ik eerder verkregen informatie nogmaals ga bekijken

29. Wanneer ik veel weet over een bepaald type ziekte en een diagnose moet stellen,

Controleer ik de meeste mogelijkheden voordat ik een beslissing neem 
Box 1. Vervolg

30. Naarmate de casus zich openbaart,

Vind ik het niet nuttig om samen te vatten als ik verder ga

Maak ik regelmatig de balans op over de gegevens en mijn ideeën

31. Wanneer ik mijn diagnostische beslissingen neem,

Is er vaak informatie overgebleven die ik gewoon $\quad \square \quad \square \quad \square \quad \square \quad \square \quad \square \quad$ Heb ik meestal alle informatie wel in overweging genomen vergeten was

32. Wanneer ik een idee heb wat er met de patiènt aan de hand zou kunnen zijn,

Vind ik het het prettigst als ik het kan vervolgen

zonder afgeleid te worden

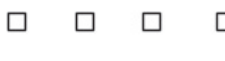

Vind ik het niet erg om een andere weg in te slaan en later terug te gaan naar mijn originele ideeën

33. Als ik een idee krijg over wat er met de patiènt aan de hand kan zijn,
Kan ik gewoonlijk komen tot een specifieke diagnose
Vind ik het moeilijk deze in specifieke termen te vatten

\section{Tijdens het vraaggesprek}
Heb ik gelegenheid om mijn eigen ideeën te testen
zelfs als ik de patiënt het vraaggesprek laat sturen
$\square \square \square$
Ben ik alleen succesvol als ik zelf het vraaggesprek kan sturen

35. Met betrekking tot de keuze uit de diagnostische ideeën die ik heb,

Ben ik meestal niet in staat om de ideeën die ik had volledig uit te sluiten

36. Als ik tot een beslissing gekomen ben over een patiènt,

Ben ik nog steeds bereid van mening te veranderen

$\square$

37. Wanneer ik mijn diagnostische ideeèn overweeg, doe ik dat op basis van

De casus als geheel tot dusver

38. Wanneer ik niet weet wat ik met een klinisch vraaggesprek aan moet,

Kan ik de informatie gemakkelijk op nieuwe manieren beschouwen

39. Wanneer ik alle testen voor de actieve en passieve structuren uitvoer,

Doe ik dat als onderdeel van het routinematig

onderzoek

40. Bij het overwegen van de diagnostische mogelijkheden,

Vergelijk ik de mogelijke diagnoses en zet ze

tegenover elkaar

$\square \quad \square \quad \square$

$\square$

$\square$ Overweeg ik elke mogelijke diagnose op zichzelf

41. In termen van de manieren waarop ik een vraaggesprek voer,

Vraag ik meestal alles uit wat ik moet vragen tijdens het vraaggesprek

Items identificatie

* Flexibiliteit in het denkproces (21 items):

$4,5,11,15,16,24,28,30,32,35$

Gespiegelde items: 2, 3, 6, 23, 26, 27, 34, 36, 38, 40, 41

* Kennisstructuur (20 items): 1, 2, 8, 9, 12, 20, 31, 39

Gespiegelde items: 10, 13, 14, 17, 18, 19, 21, 22, 25, 29, 33, 37 
lation' methode omdat een eerder vertaalde versie van Beulens et al. ${ }^{23}$ niet beschikbaar was. De vragenlijst is ontworpen om twee belangrijke aspecten binnen het klinisch redeneren in subschalen te meten: de mate van flexibiliteit in het denkproces en de mate waarin er gebruik wordt gemaakt van de kennisstructuur in het geheugen. Het vertaalproces, de expert-, face-, en constructvaliditeit, evenals de test-hertestbetrouwbaarheid, de responsiviteit en de hanteerbaarheid van deze vragenlijst zijn eerder beoordeeld. ${ }^{24}$ De vragenlijst voldoet aan de bovenstaande klinimetrische kwaliteitseisen.

De vragenlijst omvat 41 items over het klinisch redeneren, waarvan 21 vragen de flexibiliteit in het denkproces meten en 20 vragen de kennisstructuur meten. De antwoordopties zijn in een zespunts Likertschaal uitgewerkt. Foutief ingevulde scores (0 en 7) worden als 'missing values' meegenomen. Om de somscores te kunnen berekenen worden de 'missing values' bij de betreffende vragen als gemiddelde score voor de betreffende studenten ingevuld. Eén vraag (39) is herschreven zodat deze voor de fysiotherapie relevant is. In de analyses is één vraag (uit de reeks flexibiliteit in het denkproces) niet meegenomen (41) omdat de vertaling onduidelijk was. In box is de juiste vertaling opgenomen. De vragen binnen beide domeinen (flexibiliteit in het denkproces en kennisstructuur) zijn ad random in de vragenlijst geplaatst en ad random gespiegeld.

Bordage et al. ${ }^{8}$ hanteren bij de interpretatie van de resultaten de volgende criteria voor vierdejaars studenten geneeskunde: 85.6 voor de subschaal flexibiliteit in het denkproces en 82.8 voor de subschaal kennisstructuur. Deze criteria zijn gehanteerd bij de interpretatie van de resultaten.

Aan de hand van een ongepaarde student t-toets zijn (na controle voor normaalverdelingen) de cohorten vierdejaars studenten 2004 en 2006 met elkaar vergeleken $(\mathrm{p}<0.05)$. De analyse is uitgevoerd met het SPSS programma versie 15.0.

\section{Resultaten}

Het aantal respondenten uit het cohort $2004(n=58)$ en $2006(n=34)$ bedroeg respectievelijk 64,9\% en 44,7\%. De Cronbach's alpha van de 21 vragen die de flexibiliteit in het denkproces meet en van de 20 vragen die de kennisstructuur meet is respectievelijk 0.71 en 0.82 . De groepen laten een normaalverdeling zien. In Tabel 1 zijn de somscores van de getoetste cohorten studenten weergegeven zowel als totaal van klinisch redeneren als ook voor de subschalen behorende bij de domeinen flexibiliteit in het denkproces en kennisstructuur.

De t-test, uitgevoerd tussen de cohorten 2004 en 2006, laat een significant verschil zien, zowel in de totale vragenlijst $(\mathrm{p}=0.01)$

Tabel 1. Tabel t-toets.

\begin{tabular}{lccccc}
\hline & $\begin{array}{c}\text { Somscore } \\
\text { cohort 2004, } \\
\mathrm{n}=58\end{array}$ & $\begin{array}{c}\text { Somscore } \\
\text { cohort 2006, } \\
\mathrm{n}=34\end{array}$ & $\begin{array}{c}\text { Gemiddeld } \\
\text { verschil }\end{array}$ & $\begin{array}{c}\text { 95\% BI } \\
\text { (lower; upper) }\end{array}$ & Sign. \\
\hline Totaal & 176.84 & 185.94 & -9.10 & $-16.11 ;-2.10$ & $0.011^{*}$ \\
$\begin{array}{l}\text { Flexibilliteit in } \\
\text { het denkproces }\end{array}$ & 86.46 & 91.47 & -5.01 & $-8.72 ;-1.30$ & $0.009^{*}$ \\
Kennisstructur & 90.38 & 94.47 & -4.09 & $-7.84 ;-0.34$ & $0.033^{*}$ \\
\hline
\end{tabular}

* Significantieniveau op 0,05 
alsook specifiek in het domein flexibiliteit in het denkproces $(\mathrm{p}=0.01)$ en in het domein kennisstructuur $(\mathrm{p}=0.03)$.

De studenten van beide cohorten, dus ook de studenten die het meer traditionele onderwijs volgden, scoren in beide domeinen hoger dan de door Bordage et al. ${ }^{8}$ aangegeven referentiewaarden voor vierdejaars geneeskundestudenten.

\section{Conclusie en discussie}

De studenten uit het cohort 2006 scoorden significant beter in vergelijking met de studenten uit het cohort 2004. Beide groepen studenten studeerden in een probleemgestuurde leeromgeving. Het toepassen van de PGO-methodiek de '7-sprong'25 dwingt de studenten op gestructureerde wijze hun kennis te ordenen. Zowel stap 4 van de 7-sprong, waar studenten een eerste structuur in hun kennis aanbrengen, als stap 7, waar ze hun kennisstructuur toetsen en misconcepties aan het licht brengen, zal er voor zorgen dat kennis beter verankerd wordt met reeds bestaande concepten. Het in de authentieke context geïntegreerd toepassen van kennis en vaardigheden (uitgewerkt in het 4 C/ID-model) blijkt het flexibel kunnen aanwenden van kennis, alsmede van de kennisstructuur als voorwaarde voor het klinisch redeneren, gunstig te beïnvloeden.

Helaas was het gebruikte meetinstrument (DTI) niet beschikbaar op het moment dat het cohort 2004 nog derdejaars was. Het vergelijken van somscores van derdejaars studenten uit de cohorten 2004 en 2006, alvorens ze de stage ingaan, zou mogelijk meer direct iets zeggen over het gevolgde onderwijs voorafgaand aan de stage.

Bij het duiden van de resultaten moet rekening gehouden worden met een aantal aspecten. Ten eerste was het aantal respondenten van het cohort 2006 laag. De oorzaak hiervan zou kunnen liggen in het feit dat studenten aan het eind van hun studie minder gemotiveerd zijn vragenlijsten in te vullen. Ten tweede geeft de respons op de gebruikte vragenlijst alleen inzicht in de cognitieve activiteiten, zoals die door de student zelf geïnterpreteerd worden, en is er geen sprake van een objectieve uitkomstmaat. Tevens is de interne consistentie van de subschalen van deze vragenlijst enkel beoordeeld aan de hand van de Cronbach's alfa. Een factoranalyse zou meer uitsluitsel kunnen geven over de consistentie van de domeinen. ${ }^{26}$ Een alternatief meetinstrument om het klinisch redeneren te 'meten' zou de SCT (Script Concordance Test) kunnen zijn. ${ }^{27}$ Dit meetinstrument was bij afname in 2008 echter niet beschikbaar voor de opleiding Fysiotherapie.

Hoewel een direct vergelijk van de scores van de fysiotherapiestudenten met de onderzoekspopulatie in de studie van Bordage et al. ${ }^{8}$ (studenten geneeskunde) niet mogelijk is, zijn de referentiewaarden voor de "Diagnostic thinking inventory" vragenlijst wel indicatief voor de scores van de studenten fysiotherapie; de studenten fysiotherapie scoorden op deze vragenlijst hoger. Een direct vergelijk is niet mogelijk omdat het bijvoorbeeld onduidelijk is of de studenten geneeskunde in het onderzoek van Bordage et al. stage liepen, hetgeen wel het geval was voor de studenten van de opleiding Fysiotherapie. ${ }^{8}$ Ook ontbreekt in deze studie inzicht in het curriculum van de studenten geneeskunde.

\section{Aanbevelingen voor verder onderzoek}

Het is van belang om ook bij de vierdejaars studenten uit het cohort 2007, die in het schooljaar 2011 hun stage hebben afgerond, nogmaals te onderzoeken of de ingezette verbetering in klinisch redeneren zich stabiliseert. Immers, met dit onderzoeksdesign en een analyse met een ongepaarde t-toets kunnen causale verbanden niet worden aangetoond en bestaat er weinig zekerheid of de gemeten verschillen tussen de groepen door het gevolgde onderwijs tot 
stand zijn gekomen. Een objectievere maat zou het vergelijken van performance assessments met simulatiepatiënten vóór en ná het doorvoeren van de onderwijsvernieuwing zijn.

De Script Concordance Test (SCT) zou een meer objectieve uitkomstmaat ten aanzien van het klinisch redeneren kunnen geven omdat ook de visie van experts bij de beoordeling van het bereikte niveau wordt meegenomen. Het betreft een innovatieve schriftelijke toets die beoogt het klinisch redeneren te meten aan de hand van korte klinische casus relevant voor de beroepspraktijk. De SCT meet de juiste interpretatie van de beschikbare data ${ }^{28}$, de omvang en kwaliteit van mentale scripts ${ }^{29}$ en de competentie om hypotheses te testen en beslissingen te nemen onder onzekere omstandigheden. ${ }^{30}$ Het is echter nogal bewerkelijk om een SCT te construeren. Voorbereidingen om een dergelijk instrument voor opleidingen Fysiotherapie te ontwikkelen zijn inmiddels in gang gezet.

Eerdere studies laten zien dat het klinisch redeneren door veel factoren wordt beïnvloed. Naast sociaal-communicatieve vaardigheden zijn zelfbeeld, persoonlijke normen en waarden, het professionele referentiekader maar ook motieven en persoonskenmerken belangrijke factoren in dit handelen. ${ }^{31}$ Croskerry geeft meer dan 30 mogelijkheden aan waardoor het klinisch redeneren negatief kan worden beïnvloed. ${ }^{32}$ Norman wijdt cognitieve fouten aan de volgende omstandigheden: a) studenten vinden de eerste diagnose waaraan ze denken vaak de beste, b) er wordt niet verder gekeken dan de basis en daardoor worden uitzonderingen niet gezien, c) de basis wordt vergeten en daardoor is het te moeilijk om te denken in uitzonderingen, d) er wordt alleen maar naar bevestiging van de vermeende diagnose gekeken en e) er wordt te snel gestopt met redeneren. ${ }^{18}$ Het strekt dan ook tot aanbeveling zich te blijven inspannen om factoren die het klinisch redeneren bevorderen te onderzoeken en de groei hiervan ten gevolge van het genoten onderwijs in kaart te brengen met wetenschappelijk verantwoorde (psychometrische) meetinstrumenten. De geluiden uit het werkveld tot nu toe over de toegenomen vaardigheid in klinisch redeneren van studenten na de onderwijsvernieuwing met het 4C/ID-model zijn veelbelovend. Metingen met een langere follow-up periode kunnen hier meer zekerheid bieden.

\section{Literatuur}

1. Eva KW. What every teacher needs to know about clinical reasoning. Med Educ 2005;39:98106.

2. Harasym PH, Tsai TC, Hemmati P. Current trends in developing medical students' critical thinking abilities. Kaohsiung J Med Sci 2008;24:341-55.

3. Bissessur SW, Geijteman EC, Al-Dulaimy M, Teunissen PW, Richir MC, Arnold AE et al. Therapeutic reasoning: from hiatus to hypothetical model. J Eval Clin Pract 2009;15:985-9.

4. Elstein AS. Thinking about diagnostic thinking: a 30-year perspective. Adv Health Sci Educ Theory Pract 2009;14 Suppl 1:7-18.

5. Norman G. Dual processing and diagnostic errors. Adv Health Sci Educ Theory Pract 2009;14 Suppl 1:37-49.

6. Mamede S, Schmidt HG, Rikers R. Diagnostic errors and reflective practice in medicine. $\mathrm{J}$ Eval Clin Pract 2007;13:138-145.

7. Van Loon LM. Het beroepsprofiel van de fysiotherapeut. Amersfoort: Koninklijk Nederlands Genootschap voor Fysiotherapie (KNGF); 2006. [The professional profile of the physiotherapist].

8. Bordage G, Grant J, Marsden P. Quantitative assessment of diagnostic ability. Med Educ 1990;24:413-425.

9. Harasym PH, Tsai TC, Hemmati P. Current trends in developing medical students' critical thinking abilities. The Kaohsiung Journal of Medical Sciences 2008;24:341-355.

10. Van Loon L. Het beroepsprofiel van de fysiotherapeut. Amersfoort: Koninklijk Nederlands Genootschap voor Fysiotherapie (KNGF); 2006. [The professional profile of the physiotherapist].

11. Graber ML, Franklin N, Gordon R. Diagnostic error in internal medicine. Arch Intern Med 2005;165:1493-1499.

12. Gerards-Last D, van den Broek-van den Boorn M, Nelissen-de Vos Y. Het competentiegericht curriculum met als leidraad: 4C/ID. Onderzoek van Onderwijs 2007;36. [The competencybased curriculum, based on 4C/ID]. 
13. Janssen-Noordman AMB, van Merriënboer JJG, van der Vleuten CPM, Scherpbier A. Innovatief onderwijs ontwerpen; via leertaken naar complexe vaardigheden. Tijdschrift voor Medisch Onderwijs 2003;22(4):187-195.[[Innovative educational design: from learning tasks to complex skills. Netherlands Journal of Medical Education 2003;22(4):187-195].

14. Hoogveld B, Janssen-Noordman AMB, van Merriënboer $\mathrm{J}$. Innovatief onderwijs in de praktijk. Toepassingen van het 4C/ID-model. Groningen: Noordhoff; 2011. [Innovative education in practice. Applications of the 4C/ID model].

15. Janssen-Noordman AMB, van Merriënboer JJG. Innovatief onderwijs ontwerpen: via leertaken naar complexe vaardigheden: WoltersNoordhoff; 2002. [Innovative educational design: from learning tasks to complex skills].

16. Van Merriënboer JJG, Kirschner PA. Ten steps to complex learning: A systematic approach to four-component instructional design: Lawrence Erlbaum; 2007.

17. Van Merriënboer JJG. Training complex cognitive skills: A four-component instructional design model for technical training: Educational Technology Pubns; 1997.

18. Norman GR, Eva KW. Diagnostic error and clinical reasoning. Med Educ 2010;44:94-100.

19. Edwards I, Jones M, Carr J, Braunack-Mayer A, Jensen GM. Clinical reasoning strategies in physical therapy. Physical Therapy 2004;84:312.

20. Ramaekers S, Kremer W, Pilot A, Beukelen P, Keulen H. Assessment of competence in clinical reasoning and decision-making under uncertainty: the script concordance test method. Assessment \& Evaluation in Higher Education 2010;35:661-673.

21. Pool A. Verder leren denken dan de directe handeling. Onderwijs en Gezondheidszorg 2007;31: 215-219. [Learning how to think beyond immediate action. Education and Health Care 2007; 31:215-219].

22. Gloudemans H, Schalk R, Reynaert W. Kritisch denken als onderscheid. Onderwijs en Gezondheidszorg 2010;1:3-7. [Critical thinking makes the difference. Education and Health Care 2010;1:3-7]

23. Beullens J, van Damme B, Struyf E. Ontwikkelen probleemoplossingsgerichte klinische colleges het diagnostisch denken en blijkt dit uit het extended-matching examen? Tijdschrift voor Medisch Onderwijs 2007;26:(3): 118-127. [Diagnostic ability in relation to clinical seminars and extended-matching questions examination. Netherlands Journal of Medical Education 2007;26(3):118-127].
24. Neijnens VGL, Oving IG. Klinisch Redeneren Het proces tijdens het fysiotherapeutisch methodisch handelen in kaart gebracht [Bachelor]. Heerlen: Hogeschool Zuyd; 2010. [Mapping the processes during systematic activities in physiotherapy].

25. Schmidt HG, Moust JHC. Probleemgestuurd onderwijs: praktijk en theorie. Groningen: Wolters-Noordhoff; 1998. [Problem-based learning: practice and theory].

26. Cronbach LJ. Coefficient alpha and the internal structure of tests. Psychometrika 1951;16:297334.

27. Fournier JP, Demeester A, Charlin B. Script concordance tests: guidelines for construction. BMC Medical Informatics and Decision Making 2008;8:18.

28. Sibert L, Charlin B, Corcos J, Gagnon R, Grise $\mathrm{P}$, Vleuten $\mathrm{C}$. Stability of clinical reasoning assessment results with the Script Concordance test across two different linguistic, cultural and learning environments. Med Teach 2002;24:522527.

29. Charlin B, Roy L, Brailovsky C, Goulet F, van der Vleuten C. The Script Concordance test: a tool to assess the reflective clinician. Teach Learn Med 2000;12:189-195.

30. Charlin B, van der Vleuten C. Standardized assessment of reasoning in contexts of uncertainty. Evaluation \& the Health Professions 2004;27:304.

31. Pool A. Het gebruik van casuïstiek binnen onderwijs en gezondheidszorg. Onderwijs en Gezondheidszorg 2007;31:177-181. [Case-based learning in education and health care].

32. Croskerry P. The importance of cognitive errors in diagnosis and strategies to minimize them. Acad Med 2003;78:775.

De auteurs:

Drs. Dorien Gerards-Last, onderwijswetenschapper en fysiotherapeut. *

Dr. Jacques Geraets, epidemioloog, gezondheidswetenschapper en fysiotherapeut. *

* Beiden zijn werkzaam bij de Opleiding Fysiotherapie, Faculteit Gezondheid en Techniek, Hogeschool Zuyd te Heerlen.

Correspondentieadres:

Drs.T.Gerards-Last,t.gerards@hszuyd.nl

Dr. J. Geraets, Nieuw Eyckholt 300, 6400 AN Heerlen. Tel: 045-4006273; fax: 045-4006369;

e-mail:j.j.geraets@hszuyd.nl

Belangenconflict: geen gemeld

Financiële ondersteuning: geen gemeld 


\section{Summary}

Introduction: Mental processes leading to the right decisions in physiotherapeutic practice are referred to as clinical reasoning. It is generally assumed that clinical reasoning requires flexibility of thinking and a well-structured knowledge base.

Objective: This study investigated students' perceptions of learning about clinical reasoning in order to answer the question whether competence-based education (CBE) based on the four component instructional design (4 C/ID) model was superior to traditional problem-based learning $(P B L)$ in enhancing flexibility of thinking and structuring of knowledge.

Method: We administered a questionnaire about clinical reasoning with subscales on flexibility of thinking and knowledge structure to the fourth year physiotherapy students of the entering cohorts of $2004(N=58)$ and $2006(N=34)$ at Zuyd University, Heerlen, the Netherlands. The cohort of 2004 attended a traditional PBL curriculum and the 2006 cohort attended a competence-based curriculum based on the 4C/ID model. We used an unpaired student t-test to compare the responses to the questionnaire of the two cohorts.

Results: There was a statistically significant improvement in clinical reasoning among the students attending the competence-based curriculum compared to the students of the PBL curriculum (clinical reasoning: $p=0.01$ ), specifically in flexibility of thinking ( $p=0.01)$ and structure of knowledge ( $p=0.03)$.

Conclusion and discussion: Further studies should investigate how competence-based learning promotes students' clinical reasoning skills, factors influencing this process and objective instruments for evaluating clinical reasoning. (Gerards-Last D, Geraets J. An investigation of clinical reasoning in physiotherapy education. Netherlands Journal of Medical Education 2011;30(5):226-236.) 